\title{
Radish Planting Date and Nitrogen Rate for Cover Crop Production and the Impact on Corn Yields in Upstate Missouri
}

\author{
Leah Sandler ${ }^{1}$, Kelly A. Nelson ${ }^{2} \&$ Christopher J. Dudenhoeffer ${ }^{1}$ \\ ${ }^{1}$ Lee Greenley Jr. Memorial Research Center, University of Missouri, Novelty, MO, USA \\ ${ }^{2}$ Division of Plant Sciences, University of Missouri, Novelty, MO, USA \\ Correspondence: Kelly A. Nelson, University of Missouri, Greenley Research Center, Novelty, MO 63460, USA. \\ Tel: 1-660-739-4410. E-mail: nelsonke@missouri.edu
}

\author{
Received: February 24, 2015 Accepted: March 23, 2015 Online Published: May 15, 2015 \\ doi:10.5539/jas.v7n6p1 URL: http://dx.doi.org/10.5539/jas.v7n6p1
}

\begin{abstract}
Cover crops can increase yield of a marketable crop, offer greater yield stability, reduce fertilizer inputs, suppress weeds, and interrupt disease or pest cycles. Producers increasingly look to radish (Raphanus sativus L.) as a cover crop, but integrating it into a cropping system with corn (Zea mays L.) and soybean [Glycine max (L.) Merr.] has been difficult. Radish following wheat (Triticum aestivum L.) may provide more options for farmers. Few studies have tested the effects of nitrogen $(\mathrm{N})$ rates on radish production for a dual purpose cover/forage crop or whether additional $\mathrm{N}$ is needed because radish is often used to trap $\mathrm{N}$. This study evaluated radish planting date (1 Aug., 15 Aug., 29 Aug., and 11 Sep. in 2012 and 2013) and $\mathrm{N}$ fertilizer amount (0, 17, 33, and $67 \mathrm{~kg} \mathrm{~N} \mathrm{ha}{ }^{-1}$ ) on radish heights, chlorophyll content, and biomass production as well as their impact on corn yields the next year (2013 and 2014). Across planting dates and years, non-fertilized controls had shorter radishes than any $\mathrm{N}$ rate, while radish chlorophyll content increased as $\mathrm{N}$ rates increased. Chlorophyll and biomass content generally did not significantly increase above $33 \mathrm{~kg} \mathrm{~N} \mathrm{ha}^{-1}$. Radish foliage dry biomass production was 820 to $1670 \mathrm{~kg} \mathrm{ha}^{-1}$ greater at the first planting date (1 Aug.) in 2012 and 2013 than the other planting dates. Winter annual weed suppression was greatest at the first planting date in 2012. No differences in winter annual weed suppression were observed in 2013 compared to the other planting dates. Radish planting date did not affect corn yield the following year (2013 and 2014). This study demonstrates the benefits of planting radishes in late summer prior to $1 \mathrm{Sep}$. and fertilizing with $33 \mathrm{~kg} \mathrm{~N} \mathrm{ha}^{-1}$ for optimum radish biomass production following wheat in upstate Missouri.
\end{abstract}

Keywords: cover crop, corn, forage, nitrogen, no-till, radish, seeding date

\section{Introduction}

Cover crops are plants grown in a rotation when main crops are absent (Mohammadi, 2013). Cover crops offer many benefits, the most direct positive of which is increased yield of a marketable crop. They also increase yield stability, reduce fertilizer inputs, suppress weeds, break disease or pest cycles, increase soil and water quality, and increase nutrient cycling efficiency (Thiessen Martens et al., 2001; Snapp et al., 2005; Hoffbeck et al., 2008). Cover crops also aid in soil conservation, and reduce soil erosion, nitrate leaching, and chemical runoff (Snapp et al., 2005). Such crops increase water infiltration, retain soil moisture, improve soil tilth, and increase nutrient cycling efficiency (Teasdale, 1996). Finally, planting a cover crop replaces unmanageable weed populations such as common lambsquarters (Chenopodium album L.), redroot pigweed (Amaranthus retrofelxus L.), and some annual grasses with a manageable crop or mulch population (Teasdale, 1996). Producers considering using cover crops should determine which benefits they seek, as well as determining the seeding timing and type. For winter cover crops, a cash crop does not have to be sacrificed, and planting normally occurs in the fall after harvest of an annual cash crop (Snapp et al., 2005).

Radish's (Raphanus sativus L.) myriad of benefits, include improving soil aeration, suppressing weeds, capturing nutrients, and possibly increasing yields of grain crops in the crop rotaiton. Sojka et al. (1991) noted that, in addition to suppressing weeds, radish's typical cover-crop benefits include reducing soil erosion, increasing soil moisture infiltration and adding organic matter to soil. In Maryland, forage radishes planted before 1 Sep. produced 3.9 to $6.6 \mathrm{Mg} \mathrm{ha}^{-1}$ shoot dry matter and 1.3 to $3.2 \mathrm{Mg} \mathrm{ha}^{-1}$ tuber dry matter (Lawley et al., 2011). Although corn (Zea mays L.) tested after radish and other cover crops showed no yield difference, corn populations decreased in the several site years following annual ryegrass (Lolium perenne L.). Radishes have a small C:N ratio. 
Lawley (2011) found that cover crops that did not overwinter, such as radish, left less residue. This simplifies spring seeding, provides warmer soils, and allows for more timely planting of subsequent crops compared to cover crops that overwinter, such as ryegrass (Lawley et al., 2011).

Radishes' planting date influences crop production (Pell at al., 1993; Pandey et al., 2009; Alam et al., 2010; Ebrahimi et al., 2013), including the vegetative and reproductive growth periods as well as the balance between them, which affects yield (Ebrahimi et al., 2013). An appropriate sowing date helps reduce damage from cold, heat, pests, diseases, and weeds. This favorable timing also coincides with climatic factors affecting production, such as coincidence of flowering with suitable temperature, which aids in plant establishment (Ebrahimi et al., 2013). Ideal radish sowing times vary depending on environment and variety. Growers often manipulate sowing times for better growth and yields (Alam et al., 2010). Timing of planting may be significant due to available light. Light treatments affect radish growth and yield (Schmitt et al., 1986; Pell et al., 1993). In a pot experiment, radish growth rates and mass decreased with decreasing light (Schmitt et al., 1986), and photoperiod influenced biomass partitioning (Pell et al., 1993). In addition to the amount of light available, the season may impact radish production (Pell at al., 1993). In growth chambers, radishes exhibited a more adverse response to soil moisture deficits in the spring than fall. Soil moisture reduced $\mathrm{CO}_{2}$ fixation and thus subsequent biomass accumulation (Pell et al., 1993). The authors hypothesize that spring conditions led to a large relative growth rate and faster water loss by the shoot, thus favoring a negative impact of reduced soil moisture which was more evident in the spring. It is important that timing of crop cycles matches rainfall cycles (Caviglia et al., 2004).

Establishing radish after wheat (Triticum aestivum L.) may foster both growth and cover crop benefits. The timing of establishing a second crop early can be important because, after 1 Dec., the rate of decline in yield with delayed sowing is about $1.3 \%$ per day for sole-crops and $0.5 \%$ per day for double-crops (Caviglia et al., 2011). Sanford et al (1973) observed that no-till double-crop systems provided the least delay in establishing a second crop. Water available to plants affected winter wheat grain production in a study of tillage and $\mathrm{N}$ rates on wheat production (Halverson et al., 1999). No-till and minimal tillage yielded higher than conventional tillage, with grain yields of $2022 \mathrm{~kg} \mathrm{ha}^{-1}, 1968 \mathrm{~kg} \mathrm{ha}^{-1}$ and $1801 \mathrm{~kg} \mathrm{ha}^{-1}$, respectively (Halverson et al., 1999).

In Missouri, standard practice includes adding $\mathrm{N}$ fertilizer to non-leguminous crops such as wheat and corn, regardless of the $\mathrm{N}$ form. However, few studies have evaluated how $\mathrm{N}$ rates affect radish production (Sanchez et al., 1991; Hochmuth et al., 2009) or whether $\mathrm{N}$ fertilizer is needed because radish traps $\mathrm{N}$. Nitrogen fertilizer increased seed yield of radish by $1.4 \mathrm{q} \mathrm{ha}^{-1}$, but yields increased to $2.3 \mathrm{q} \mathrm{ha}^{-1}$ when $30 \mathrm{~kg} \mathrm{ha}^{-1}$ of phosphorus was added (Sharma, 2000). In Pakistan, adding $\mathrm{N}$ fertilizer significantly increased radish biomass and yield compared to non-fertilized controls (Asghar et al., 2006). However, a Florida study found no response with N fertilizer and so did not recommend it for radish production (Hochmuth et al., 2009). Other research determined that radishes used soil mineral N, and that $\mathrm{N}$ fertilization did not increase radish yields in that system (Sanchez et al., 1991). The objective of this research was to evaluate radish planting date and $\mathrm{N}$ fertilizer rate on radish height, chlorophyll content, and biomass production as well as the impact on corn yield the following year.

\section{Materials and Methods}

Field research took place at the University of Missouri Lee Greenley Jr. Memorial Research Center near Novelty $\left(40^{\circ} 01^{\prime} \mathrm{N}, 92^{\circ} 11^{\prime} \mathrm{W}\right)$ in 2012 and 2013 while the rotational impact on corn was evaluated in 2013 and 2014, respectively. In the experiment's split-plot design, the main plot was planting date, and the sub-plot was $\mathrm{N}$ fertilizer rate. Four replications were planted in 3 by $10.5 \mathrm{~m}$ plots on a Kilwinning silt loam (fine, montmorillonitic, mesic, Vertic Ochraqualfs). In a field that had previously been winter wheat, 'Tillage radish' (Cover Crop Solutions LLC, Lititz, PA) were no-till drilled (Great Plains Ag, Salina, KS) in $19 \mathrm{~cm}$ rows at $10 \mathrm{~kg}$ seed ha ${ }^{-1}$ approximately every two weeks. In 2012, the seeding dates were 1 Aug., 17 Aug., 30 Aug., and 12 Sep. In 2013, the dates were 1 Aug., 14 Aug., 28 Aug., and 11 Sep. Planting dates were averaged as (1 Aug., 15 Aug., 29 Aug., and 11 Sep.) for figures and tables throughout the manuscript. Nitrogen in the form of ammonium nitrate (34-0-0) at 0, 17, 33 and $67 \mathrm{~kg} \mathrm{~N}$ $\mathrm{ha}^{-1}$ was applied by hand spreader across all radish planting dates on 5 Oct. 2012 and 12 Sep. 2013 . Radish foliage heights were recorded at $0,6,13,16,23,34$, and 40 days after $\mathrm{N}$ fertilizer treatment (DAT). Clethodim ((E)-2-[1-[[(3-chloro-2-propenyl)oxy]imino]propyl]5-[2-(ethylthio)propyl]-3-hydroxy-2-cyclohexen-1-one) at $0.07 \mathrm{~kg}$ ai ha ${ }^{-1}$ and crop oil concentrate at $2.4 \mathrm{~L} \mathrm{ha}^{-1}$ were applied on 29 Oct. 2012 and 12 Sep. 2013 to reduce interference with wheat. On 12 Nov. 2012 and 22 Oct. 2013, chlorophyll index measurements of the uppermost fully expanded radish leaf were determined using a SPAD meter (Minolta SPAD-502, Konica Minolta Optics, Inc.). Radish top biomass was collected from a 0.3 by 0.3 m quadrat on 13 Nov. 2012 and 12 Nov. 2013. Samples were dried and weights recorded.

Common chickweed [Stellaria media (L.) Vill.] and henbit (Lamium amplexicauli L.) suppression was visually 
rated $(0=$ no control to $100=$ complete control) prior to a burndown herbicide application in the spring the following year prior to planting corn (2013 and 2014). Glyphosate ( $N$-(phosphonomethyl)glycine) at $0.84 \mathrm{~kg}$ ae ha ${ }^{-1}$ plus saflufenacil (N'-[2-chloro-4-fluoro-5-(3-methyl-2,6-dioxo-4-(trifluoromethyl)-3,6-dihydro-1(2H)-pyrimidinyl)be nzoyl]-N-isopropyl-N-methylsulfamide) at $0.025 \mathrm{~kg}$ ai ha ${ }^{-1}$ plus diammonium sulfate (DAS) at $20 \mathrm{~g} \mathrm{~L}^{-1}$ plus methylated seed oil at $1 \%$ vol./vol. plus was applied on 26 April 2013. A premix of acetochlor (2-chloro-2'-methyl-6'-ethyl-N-ethoxymethylacetanilide) plus atrazine (2-chloro-4-(ethylamino)-6-(isopropylam ino)-s-triazine) at $3.4 \mathrm{~kg}$ ai ha ${ }^{-1}$ plus glyphosate at $0.84 \mathrm{~kg}$ ae ha- ${ }^{-1}$ plus DAS at $20 \mathrm{~g} \mathrm{~L}^{-1}$ was applied on 6 May 2014.

Corn (DKC 62-97) was no-till planted (John Deere 7000, Moline, IL) at 81,500 seeds ha $^{-1}$ in $76 \mathrm{~cm}$ rows on 8 May 2013 and 11 April 2014. Anhydrous ammonia was applied (John Deere $2510 \mathrm{H}$, Moline, IL) preplant at $170 \mathrm{~N} \mathrm{ha}^{-1}$ on 26 April 2013 and at $160 \mathrm{~kg} \mathrm{~N} \mathrm{ha}^{-1}$ on 8 April 2014. On 27 June 2013, plots were maintained weed-free with a premixture of acetochlor plus clopyralid (3,6-dichloro-2-pyridine carboxylic acid, monoethanolamine salt) plus flumetsulam (N-(2,6-difluorophenyl)-5-methyl-1,2,4-triazolo-[1,5a]-pyrimidine-2-sulfonamide) plus at $1.2 \mathrm{~kg}$ ai $\mathrm{ha}^{-1}$ plus glyphosate at $0.84 \mathrm{~kg}$ ae ha ${ }^{-1}$ plus non-ionic surfactant at $0.25 \%$ vol./vol. on 21 May followed by glyphosate at $0.84 \mathrm{~kg}$ ae ha ${ }^{-1}$ plus mesotrione (2-[4-(methylsulfonyl)-2-nitrobenzoyl]-1,3-cyclohexanedione) at $0.105 \mathrm{~kg}$ ai ha ${ }^{-1}$ plus DAS at $20 \mathrm{~g} \mathrm{~L}^{-1}$. On 26 June 2014, there was a single postemergence application of glyphosate at at $0.84 \mathrm{~kg}$ ae ha ${ }^{-1}$ plus topramezone ([3-(4,5-dihydro-3-isoxazolyl)-2-methyl-4-(methylsulfonyl) phenyl] (5-hydroxy-1-methyl-1H-pyrazol-4-yl) methanone) at $0.012 \mathrm{~kg}$ ai ha $^{-1}$ plus crop oil concentrate at $1 \%$ vol./vol.. Corn plant density was recorded before harvest. Chlorophyll index was determined using a SPAD meter (Minolta SPAD-502, Konica Minolta Optics, Inc.) at R1 (Ritchie et al., 1993). Grain yield, moisture, and test weight were determined at harvest using a Wintersteiger Delta (Salt Lake City, UT) equipped with a Harvest Master BDS800 (Juniper Systems Inc., Logan, UT) system.

All data were subjected to ANOVA (SAS, 2010). Radish heights and chlorophyll content were reported separately for year, planting date, and $\mathrm{N}$ rate due to significant interactions. Radish biomass production was separated by year and planting date, but analyzed across $\mathrm{N}$ rates due to a lack of significant 2- and 3-way interactions. Winter annual weed suppression and corn main effects were presented in the absence of significant 2- and 3-way interactions, except for chlorphyll content measurements, which had a significant $\mathrm{N} x$ radish seeding date interaction. An interaction between radish seeding date and year was presented for common chickweed control, henbit control, and yield. Means were separated using Fisher's Protected LSD $(P=0.1)$.

\section{Results and Discussion}

\subsection{Environmental Conditions}

Annual precipitation for 2012 and 2013 was below the 10-year average (Figure 1). In 2012, from planting of radishes in August to a killing freeze in late Nov., rainfall was $339 \mathrm{~mm}$ (Figure 1a), compared to the 10-year average of $481 \mathrm{~mm}$. Although total precipitation for 2012 was $722 \mathrm{~mm}$, only $215 \mathrm{~mm}$ of rain fell from May through August, which was $210 \mathrm{~mm}$ below the 10-year average (data not presented). Thus, radishes were planted following drought conditions. On the last day of August, $60 \mathrm{~mm}$ of precipitation occurred from storms following Hurricane Isaac (Figure 1a). In 2013, although total precipitation was $1003 \mathrm{~mm}$ (data not presented), only 140 $\mathrm{mm}$ of rain fell from June through August, and no rain fell in August (Figure 1b). Precipitation in September and most of October was only $123 \mathrm{~mm}$, which is $58 \mathrm{~mm}$ below the 10 -year average. The last two days of October saw $77 \mathrm{~mm}$ of rainfall. And so conditions for radishes in 2013 were drier than 2012.

The summer of 2012's abnormally high temperatures averaged $23.7{ }^{\circ} \mathrm{C}$ from May through August, with $30.7{ }^{\circ} \mathrm{C}$ as the average high (Figure 2a). During the August-October radish growth period, the average temperature was $17.4{ }^{\circ} \mathrm{C}$. In contrast, 2013 was relatively cool, with an average average high summertime temperature of $27.3^{\circ} \mathrm{C}$ and an average temperature of $21.2^{\circ} \mathrm{C}$ (Figure $2 \mathrm{~b}$ ). The July-October average temperature was $19.9^{\circ} \mathrm{C}$. Due to below-average rainfall and high average temperatures, particularly in 2012, the results of this research during 2012 were achieved under drought conditions and in 2013 under "flash drought" conditions.

\subsection{Radish Height}

Planting date and $\mathrm{N}$ amount affected radish heights (Table 1). Across planting dates, radish heights reached a maximum on 26 Oct. 2012 (23 DAT) and 22 Oct. 2013 (40 DAT) (Table 1 and Figure 3). In general, earlier planting dates had taller radishes than later plantings for all measurement dates across $\mathrm{N}$ rates (Table 1). In 2012, the first planting date was taller than the rest, with the exception of 34 DAT for 17 and $67 \mathrm{~kg} \mathrm{~N}^{-1}$, when the first and second planting dates were taller than the other three planting dates. In 2013, the first planting date had greater heights than the other planting dates, with the exception of 13 and 40 DAT at $67 \mathrm{~kg} \mathrm{~N} \mathrm{ha}^{-1}$ when the first two planting dates were taller than the last two (Table 1). 

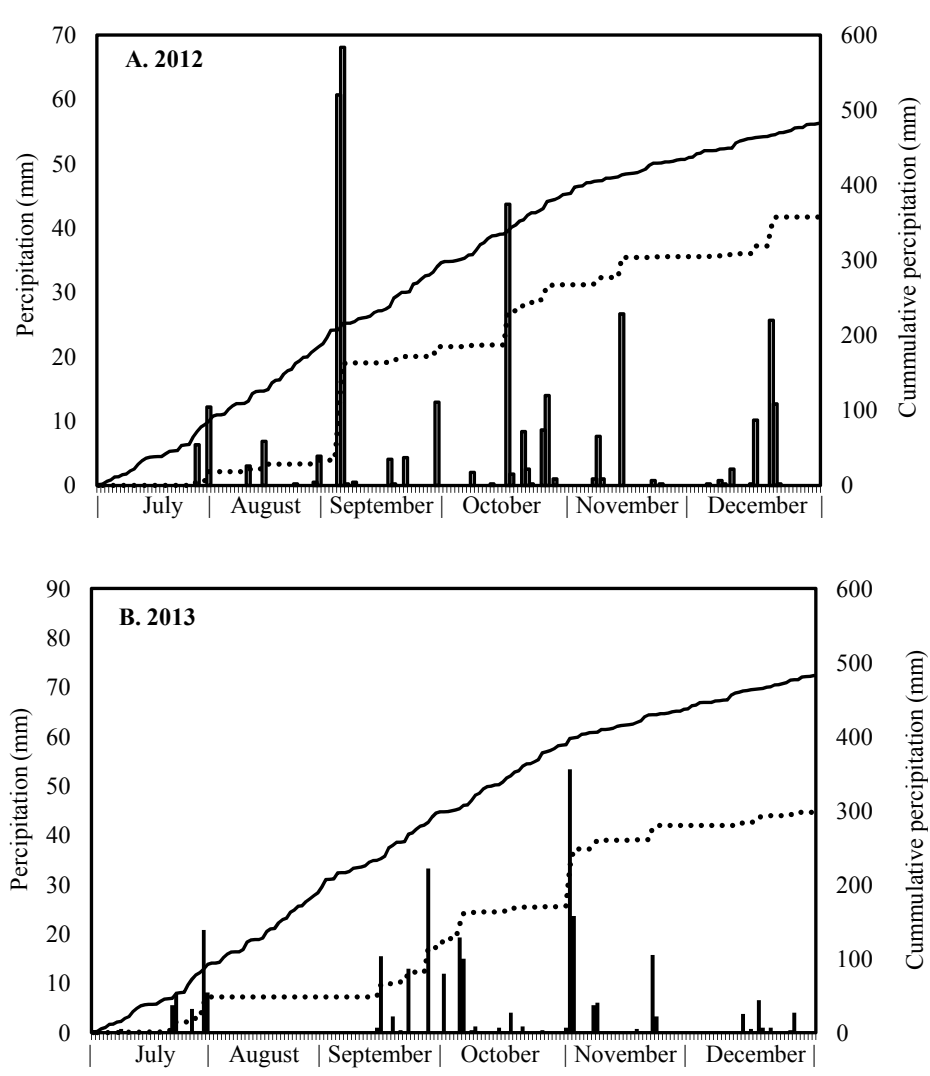

Figure 1. Daily (bar) and cumulative precipitation data for individual years (dash line) and 10-year average (solid line) for experiments in 2012 (A) and 2013 (B)

Nitrogen rates also impacted radish height. Across planting date and year, non-fertilized controls generally had shorter radishes than any $\mathrm{N}$ amount, indicating the need for additional $\mathrm{N}$ to maximize radish production for livestock grazing. In 2012, the $\mathrm{N}$ amount with the greatest radish heights across planting date was $33 \mathrm{~kg} \mathrm{~N} \mathrm{ha}^{-1}$ (Figure 1). The $67 \mathrm{~kg} \mathrm{~N} \mathrm{ha}^{-1}$ amount did not increase heights (Figure 1). However, 2013's results were different. With the exception of 13 DAT at the first planting date; 6, 13, and 40 DAT at the second planting; 13 and 40 DAT at the third planting; and 6 DAT at the fourth planting, radish heights showed no differences due to N rates, which was probably due to limited rainfall during this period (Table 1). 

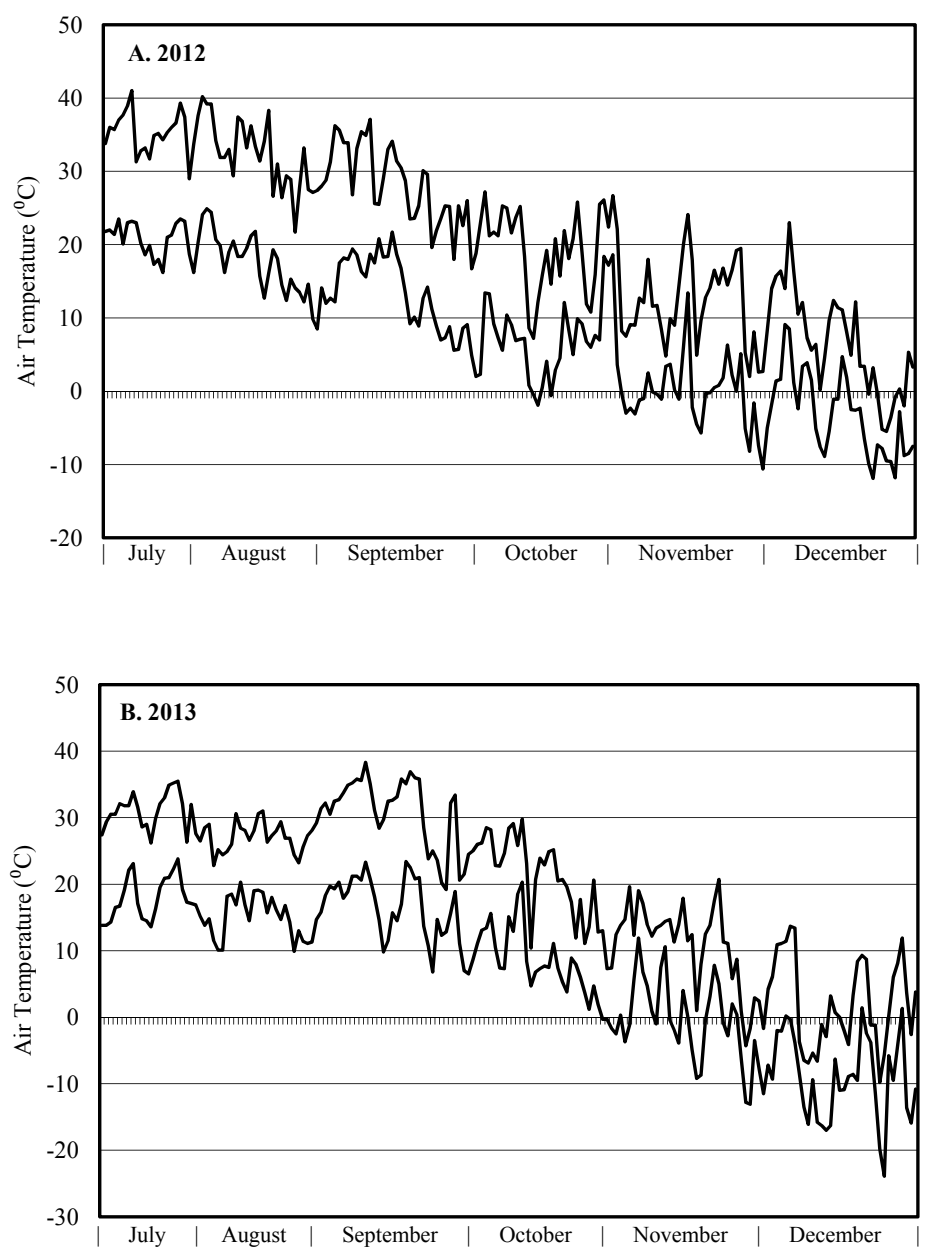

Figure 2. Daily maximum and minimum air temperature data for experiments in 2012 (A) and 2013 (B)

The few prior studies of the influence of planting date on radish heights, support this study's results that earlier dates foster greater growth. In other studies, radishes planted earlier had greater yields than those planted later (Pandey et al., 2009; Alam et al., 2010; Ebrahimi et al., 2013). However, available light affected crop growth rates (Liu et al., 2013; Zhang et al., 2014). According to a study in California, a 16-hour photoperiod was optimal for flowering of radish (Suge \& Rappaport, 1968). It is probable that radishes planted earliest had the best light as well as temperature conditions for optimal growth and height (Figure 3). Radishes reached maximum height during the third week of Oct. (Figure 3, Table 1). Finally, research completed in India reported that radish height increased with $\mathrm{N}$ rate by 8.6 to $22 \mathrm{~cm}$ compared to the non-fertilized control (Sharma, 2000). The authors attributed this to possible increased cell division and elongation (Sharma, 2000). Similar patterns occurred with increased radish height as $\mathrm{N}$ rates increased. Although this study did not measure residual $\mathrm{N}, 33 \mathrm{~kg} \mathrm{~N} \mathrm{ha}^{-1}$ is recommended for optimal radish heights. 
Table 1. Radish heights at all four planting dates 6, 13, 16, 23, 34, and 40 days after fertilizer treatment (DAT).

Data were separated by $\mathrm{N}$ rates $\left(\mathrm{kg} \mathrm{ha}^{-1}\right)$ and planting dates in 2012 and 2013

\begin{tabular}{|c|c|c|c|c|c|c|c|c|c|c|c|}
\hline \multirow{2}{*}{ DAT } & \multirow{2}{*}{$\begin{array}{l}\text { Radish } \\
\text { seeding date }\end{array}$} & \multicolumn{5}{|c|}{2012} & \multicolumn{5}{|c|}{2013} \\
\hline & & $0^{\ddagger}$ & 17 & 33 & 67 & $\operatorname{LSD}(P=0.1)$ & 0 & 17 & 33 & 67 & $\operatorname{LSD}(P=0.1)$ \\
\hline & & ---- & & & 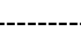 & --- & -------- & - & 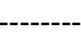 & ----- & ----י- \\
\hline \multirow[t]{5}{*}{6} & 1 Aug. & 31.1 & 33 & 34.9 & 32.4 & 3.8 & 27.9 & 27.3 & 30.5 & 26 & 6.1 \\
\hline & 15 Aug. & 25.4 & 25.4 & 25.4 & 25.4 & NS & 15.2 & 16.5 & 19.7 & 17.8 & 1.8 \\
\hline & 29 Aug. & 20.3 & 20.3 & 20.3 & 20.3 & NS & 6.4 & 8.9 & 7.6 & 7.6 & 0.8 \\
\hline & 11 Sep. & 10.2 & 10.2 & 10.2 & 10.2 & NS & 2.5 & 2.5 & 3.2 & 2.5 & 4.1 \\
\hline & $\operatorname{LSD}(P=0.1)$ & 1.8 & 1.7 & 0.7 & 1.4 & & 3.3 & 3.3 & 6.1 & 4.5 & \\
\hline \multirow[t]{5}{*}{13} & 1 Aug. & 32.4 & 36.2 & 38.1 & 36.2 & 2.8 & 38.7 & 38.1 & 34.9 & 36.2 & 10.4 \\
\hline & 15 Aug. & 27.3 & 28.6 & 29.8 & 28.6 & 2.8 & 21 & 22.9 & 26 & 34.3 & 2.5 \\
\hline & 29 Aug. & 26 & 27.9 & 27.9 & 27.3 & 2.3 & 9.5 & 14 & 10.8 & 11.4 & 1.0 \\
\hline & 11 Sep. & 12.7 & 12.7 & 12.7 & 12.7 & NS & 7 & 7.6 & 8.3 & 7.6 & 4.6 \\
\hline & $\operatorname{LSD}(P=0.1)$ & 1.7 & 2.2 & 1.4 & 3.3 & & 6.7 & 4.9 & 7.5 & 5.6 & \\
\hline \multirow[t]{5}{*}{16} & 1 Aug. & 35.6 & 40.7 & 42.5 & 40.6 & 3.3 & 43.2 & 44.5 & 44.5 & 42.5 & 7.1 \\
\hline & 15 Aug. & 29.2 & 32.4 & 34.9 & 33.7 & 3.6 & 36.9 & 66.7 & 36.2 & 39.4 & 3.8 \\
\hline & 29 Aug. & 27.3 & 30.5 & 29.8 & 28.6 & 2.8 & 20.3 & 21.6 & 21 & 22.2 & 1.3 \\
\hline & 11 Sep. & 17.1 & 17.1 & 16.5 & 17.1 & 1.3 & 14 & 13.3 & 14 & 14 & 6.4 \\
\hline & $\operatorname{LSD}(P=0.1)$ & 3.6 & 4.1 & 2.7 & 2.9 & & 7.5 & 4.8 & 7.2 & 4.8 & \\
\hline \multirow[t]{5}{*}{23} & 1 Aug. & 34.9 & 41.9 & 47.6 & 47 & 4.6 & 49.5 & 45.7 & 52.7 & 49.5 & 7.6 \\
\hline & 15 Aug. & 26.8 & 36.9 & 41.3 & 40 & 3.3 & 38.7 & 37.5 & 42.5 & 45.1 & 6.6 \\
\hline & 29 Aug. & 27.3 & 35.6 & 34.9 & 38.1 & 5.3 & 31.8 & 39.8 & 27.9 & 33.7 & 2.8 \\
\hline & 11 Sep. & 19.7 & 21 & 22.2 & 22.2 & 2.5 & 22.2 & 22.2 & 22.9 & 23.5 & 11.9 \\
\hline & $\operatorname{LSD}(P=0.1)$ & 3.7 & 4.8 & 4 & 3.1 & & 13.3 & 6.3 & 8.3 & 5.7 & \\
\hline \multirow[t]{5}{*}{34} & 1 Aug. & 36.2 & 34.9 & 41.3 & 40 & 6.1 & 50.8 & 49.5 & 49.5 & 48.9 & 7.6 \\
\hline & 15 Aug. & 29.2 & 34.9 & 37.5 & 36.2 & 4.6 & 44.5 & 41.3 & 46.4 & 44.5 & 4.8 \\
\hline & 29 Aug. & 26 & 33 & 31.7 & 31.1 & 3.6 & 34.9 & 38.1 & 37.5 & 40 & 4.1 \\
\hline & $11 \mathrm{Sep}$. & 18.4 & 18.4 & 18.4 & 17.8 & 0.8 & 31.1 & 29.8 & 31.8 & 31.1 & 8.1 \\
\hline & $\operatorname{LSD}(P=0.1)$ & 4.2 & 3.1 & 3.6 & 4.3 & & 8 & 7.6 & 9 & 6 & \\
\hline \multirow[t]{5}{*}{40} & 1 Aug. & 34.3 & 36.8 & 40.6 & 38.7 & 4.1 & 55.2 & 52.1 & 52.7 & 55.9 & 11.2 \\
\hline & 15 Aug. & 27.9 & 30.5 & 33 & 34.3 & 5.8 & 45.7 & 47.6 & 50.2 & 54.6 & 8.6 \\
\hline & 29 Aug. & 26.7 & 29.2 & 31.1 & 30.5 & 3.8 & 43.8 & 40 & 43.2 & 44.5 & 4.1 \\
\hline & 11 Sep. & 19.1 & 19.1 & 19.1 & 19.1 & NS & 35.6 & 31.8 & 33 & 39.4 & 7.6 \\
\hline & $\operatorname{LSD}(P=0.1)$ & 5.3 & 5.1 & 2.8 & 3.7 & & 9.4 & 8.2 & 7.3 & 5.8 & \\
\hline
\end{tabular}

Note. ${ }^{\dagger}$ Radish planting dates were 1 Aug., 17 Aug., 30 Aug., and 12 Sep. 2012, while in 2013 radish planting dates were 1 Aug., 14 Aug., 28 Aug., and 11 Sep; ${ }^{\dagger} \mathrm{N}$ application amount $\left(0,17,33\right.$, and $\left.66 \mathrm{~kg} \mathrm{~N} \mathrm{ha}{ }^{-1}\right)$. 

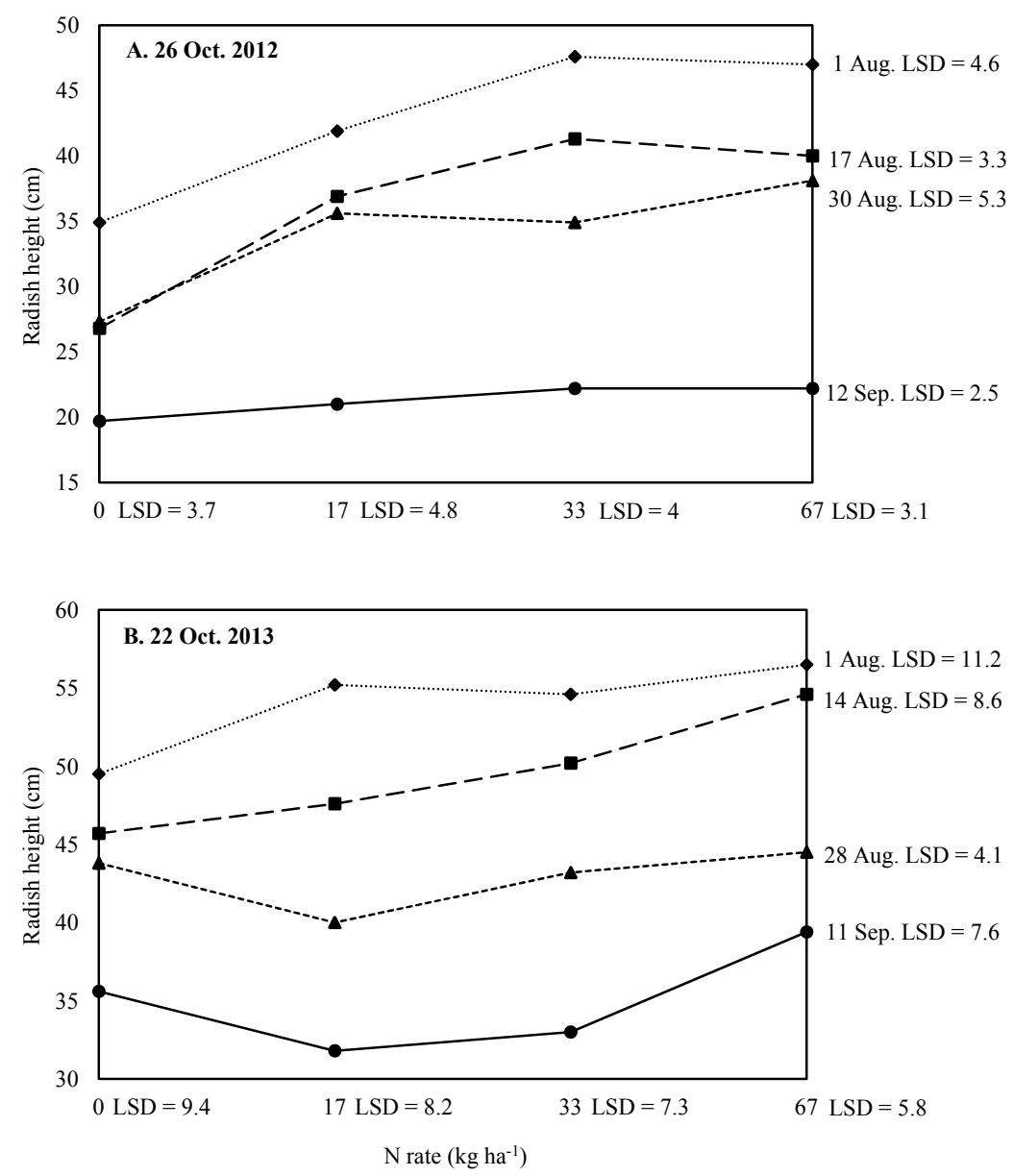

Figure 3. Radish heights for different planting dates on (A) 26 Oct. 2012 (23 days after treatment) and (B) 22 Oct. 2013 (40 days after treatment). Comparisions within a planting date are valid ( $\operatorname{LSD}(P=0.1)$ values along the right vertical axis). Comparisons within a fertilizer amount are valid ( $\operatorname{LSD}(P=0.1)$ values along the horizontal axis). Radish planting dates were labeled along the right side of the figure

\subsection{Radish Chlorophyll Index}

Radish chlorophyll content was variable and was impacted by year, planting date, and $\mathrm{N}$ rate, with a year $\mathrm{x}$ planting date $\mathrm{x} N$ rate interaction $(P=0.09)$. In 2012, the first planting date (17 Aug.) had the greatest chlorophyll content all planting dates regardless of $\mathrm{N}$ application rate (Figure 4). However, in 2013, the second and third planting dates (14 and 28 Aug.) had significantly greater chlorophyll content than the other planting dates. 

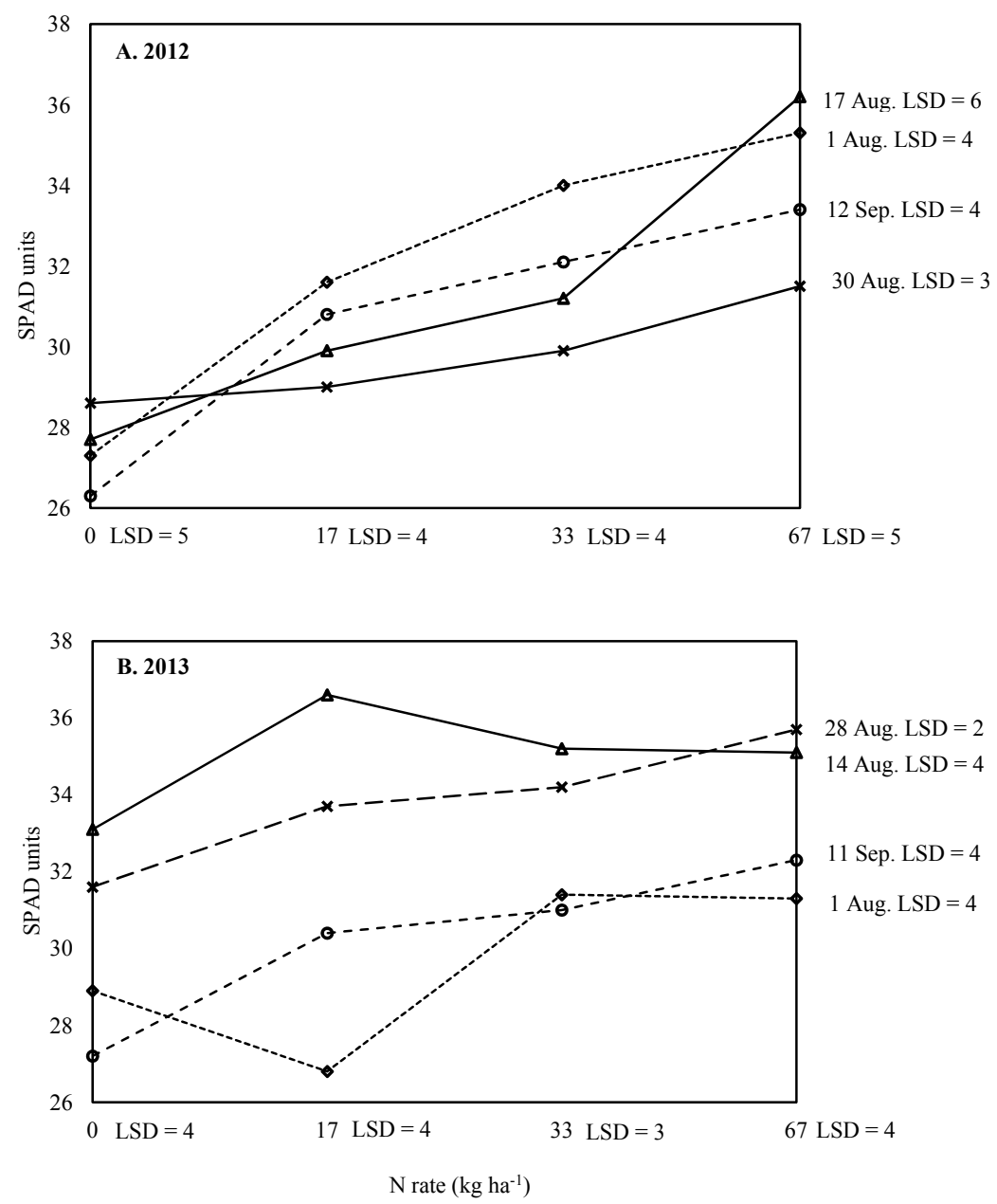

Figure 4. Chlorophyll index (SPAD units) for radish leaves. Data were separated by planting date and $\mathrm{N}$ fertilizer rate in $\left(0,17,33\right.$, and $\left.67 \mathrm{~kg} \mathrm{~N} \mathrm{ha}^{-1}\right)$ in 2012 and 2013. Comparisions within a planting date are valid (LSD $(P=0.1)$ values along the right vertical axis). Comparisons within a fertilizer amount are valid (LSD $(P=0.1)$ values along the horizontal axis). Radish planting dates were labeled along the right side of the figure

Nitrogen rates also affected radish chlorophyll content. Across planting dates in 2012, increased rates of $\mathrm{N}$ generally led to increased chlorophyll content (Figure 4). When compared to the non-treated control, $67 \mathrm{~kg} \mathrm{~N} \mathrm{ha}^{-1}$ increased chlorophyll content by 2.9 to 8.5 SPAD units except for the 12 Sep. planting date. Interestingly, chlorophyll content was not significantly greater above $33 \mathrm{~kg} \mathrm{ha}^{-1}$. In 2013, chlorophyll content did not follow N rates as closely, probably due to drier conditions which could affect the availability of $\mathrm{N}$ to the crop. At the last two planting dates (28 Aug. and 11 Sep.) the greatest chlorophyll content recorded was at the greatest $\mathrm{N}$ level $(67 \mathrm{~kg}$ $\mathrm{ha}^{-1}$ ); however, the previous two planting dates reached their largest chlorophyll levels at $17 \mathrm{~kg} \mathrm{~N}^{-1}$ (Aug. 14) and $33 \mathrm{~kg} \mathrm{~N} \mathrm{ha}^{-1}$ (1 Aug.). The chlorophyll index indicated that $33 \mathrm{~kg} \mathrm{~N} \mathrm{ha}^{-1}$ was sufficient for radishes.

\subsection{Radish Biomass}

Planting date significantly impacted radish foliage biomass yield (Figure 5). Across $\mathrm{N}$ rates, a year $\mathrm{x}$ planting date interaction $(P=0.0003)$ indicated that planting date affected radish growth. Across years, the first planting date (1 Aug.) produced the greatest biomass yields, with 820 to $1670 \mathrm{~kg} \mathrm{ha}^{-1}$ more biomass compared with the later planting dates (Figure 5). Across all planting dates, 2013 saw greater radish production than 2012. It is possible that 2013's cooler conditions provided better growing conditions for radishes regardless of planting date. The optimal planting date for the greatest biomass yields was prior to 1 Sep. 


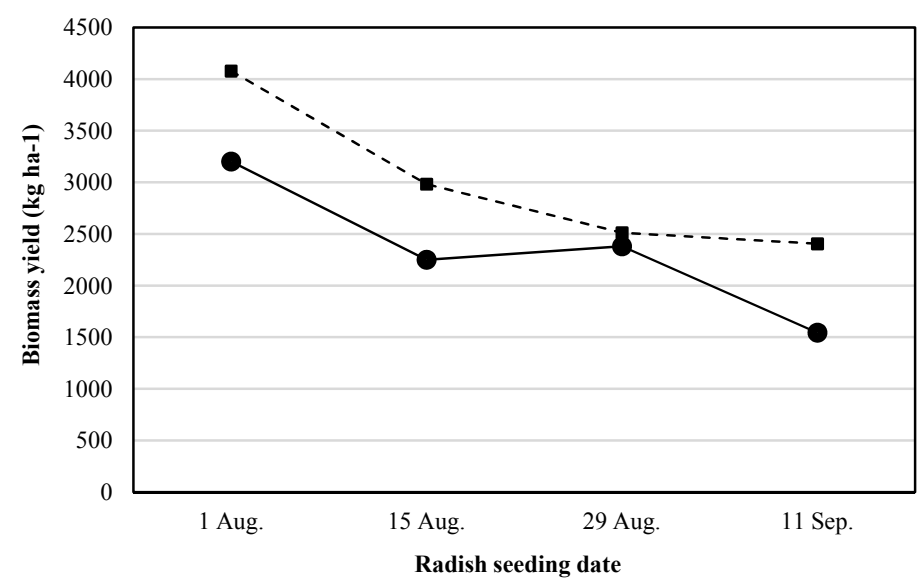

Figure 5. Radish foliage dry biomass of different planting dates in 2012 (circles and solid line, LSD $=340$ ) and 2013 (squares and dash line, LSD =635). Data were averaged over N amounts

Earlier studies evaluating how planting date affects radish production report similar findings to those shown here. In Bangladesh, sowing time significantly affected growth and yield, with the 1 Nov. planting date producing the highest root yield (81.8 $\left.\mathrm{Mg} \mathrm{ha}^{-1}\right)$ and 1 Dec. producing the lowest $\left(68.7 \mathrm{Mg} \mathrm{ha}^{-1}\right)$ (Alam et al., 2010). In addition, 1 Nov. produced the greatest root length per plant $\left(25.6 \mathrm{~cm} \mathrm{root}^{-1}\right)$, and 1 Dec. the shortest $\left(23.5 \mathrm{~cm} \mathrm{root}^{-1}\right)$. The 1 Nov. planting date produced the maximum number of leaves $\left(16.3\right.$ plant $\left.^{-1}\right)$ and leaf length $\left(59.6 \mathrm{~cm} \mathrm{leaf}^{1}\right)$ (Alam et al., 2010). All parameters showed a decreasing trend as sowing date was delayed. Pandey's study in India (2009) showed similar results when radishes were planted every ten days beginning on 9 Nov. The second planting date (19 Nov.) produced the maximum yield $\left(28.4 \mathrm{Mg} \mathrm{ha}^{-1}\right)$, root length $\left(24.45 \mathrm{~cm} \mathrm{root}^{-1}\right)$ and root weight $\left(0.097 \mathrm{~kg} \mathrm{root}^{-1}\right)$. The last planting date $\left(9 \mathrm{Dec}\right.$.) produced the least yield $\left(23.2 \mathrm{Mg} \mathrm{ha}^{-1}\right)$, root length $\left(22.31 \mathrm{~cm} \mathrm{root}^{-1}\right)$ and root weight $\left(0.008 \mathrm{~kg} \mathrm{root}^{-1}\right)$. The authors concluded that a delay in planting significantly reduced radish yield (Pandey et al., 2009). Ebrahimi's (2013) study in Iran planted black radishes (Raphanus sativus var. niger) on 10,20, and 30 Sep. Yields started at $21.9 \mathrm{Mg} \mathrm{ha}^{-1}$ for the 10 Sept. planting and decreased to $9.8 \mathrm{Mg} \mathrm{ha}^{-1}$ for the 30 Sept. planting. Later plantings had shorter days and decreased light interception, as well as fewer degree days required for crop growth (Ebrahimi et al., 2013).

In this study, radish biomass was similar at 33 and $67 \mathrm{~kg} \mathrm{~N} \mathrm{ha}^{-1}$ when averaged over planting dates (data not presented). Thus, $33 \mathrm{~kg} \mathrm{~N} \mathrm{ha}^{-1}$ was sufficient for optimal forage production during a limited autumn growth period. Although research concludes that $\mathrm{N}$ fertilizer improves crop yields (Vos et al., 1998; Kristensen \& Thorup-Kristensen, 2004; Dean \& Weil, 2009; Constantin et al., 2010; Sapkota et al., 2012) few studies evaluate how $\mathrm{N}$ fertilizer affects radish in particular. In Florida, $\mathrm{N}$ fertilization did not impact radish yield in 7 of 8 experiments (Sanchez et al., 1991). The total fertilizer-derived $\mathrm{N}$ from marketable radishes averaged only 2 to $8 \mathrm{~kg}$ $\mathrm{N}$ ha ${ }^{-1}$, prompting the authors to determine that the radishes used soil mineral $\mathrm{N}$, and that $\mathrm{N}$ fertilization did not increase radish yields in that system (Sanchez et al., 1991). The recommended $\mathrm{N}$ fertilizer amount in Pakistan was $60 \mathrm{~kg} \mathrm{~N} \mathrm{ha}^{-1}$, which increased fresh radish biomass by $73 \%$ and yield by $14 \%$, with an increase of $0.19 \mathrm{~kg} \mathrm{plant}^{-1}$ and $32 \mathrm{Mg} \mathrm{ha}^{-1}$ when compared to a non-fertilized control (Asghar et al., 2006). Based on our research, we recommend planting before 1 Sep. with at least $33 \mathrm{~kg} \mathrm{~N} \mathrm{ha}^{-1}$.

\subsection{Winter Annual Weed and Corn Response the Following Year}

The only effect of fall $\mathrm{N}$ rate on winter annual weed or corn response was its interaction with seeding date on chlorophyll index readings. An early radish planting date (1 Aug.) suppressed common chickweed and henbit greater than later planting dates in 2013 (Table 2). However, in 2014 no differences among planting dates were observed. Research has shown that Brassica species includeing radish have significant weed suppression (Altieri et al., 2011; Lawley et al., 2011, 2012; Malik et al., 2008; Norsworth, 2003; Stivers-Young, 1998; Uremis et al., 2009). Norsworthy (2003) showed that germination and radical growth of all weed species [sickle pod (Senna obtusifolia L.), prickly sida (Sida spinosa L.), and yellow nutsedge (Cyperus esculentus L.)] evaluated were reduced by extract of forage radish in comparison to non-treated controls. Greater weed suppression coincided with greater radish biomass production in 2013 (Table 2) which corresponded with Teasdale (1996) who reviewed cover crop research and reported that control of weeds increased with greater amounts of cover crop residue biomass. In western New York, Brassica cover crops including oilseed radish residues significantly suppressed 
weeds with earlier planted crops (25 Aug.) and had particularly greater winter annual weed [common chickweed (Stellaria media L.), henbit (Lamium amplexicaule L.), and malva (Malva moschata L.)] suppression than later planting dates (Stivers-Young, 1998). Corn was planted earlier in 2014 along with an autumn that was dry and the winter was extremely cold (data not presented). Taken together, these factors may explain weed suppression differences between years, which delayed the overall burndown herbicide application to an early postemergence treatment in 2013. Lawley et al. (2012) observed early spring suppression of common chickweed and henbit; however, radish showed almost complete weed control in early spring while control declined throughout the growing season as summer annual weeds started emerging. Forage radish provided complete weed suppression in early fall through winter and into early March when weed cover was only $0-3 \%$; however, weed suppression from radishes did not extend to the next growing season and a postemergence herbicide was needed to be applied to avoid a yield reduction in corn due to weed interference (Lawley et al., 2011). Thus it is possible that winter annual weed suppression was greater in 2014 due to an earlier burdown application prior to allowing growth of weeds later in the season.

Radish seeding date did not affect corn plant density. According to the chlorophyll index at R1, corn plants following early-planted radish with 17 and $33 \mathrm{~kg} \mathrm{~N} \mathrm{ha}^{-1}$ were generally greener than the non-treated control, while corn from the last planting date generally was greener when 0 or $66 \mathrm{~kg} \mathrm{~N} \mathrm{ha}^{-1}$ was applied. Differences in corn chlorophyll content varied based on radish planting date and $\mathrm{N}$ applied for radish production. Corn grain moisture $\left(188 \mathrm{~g} \mathrm{~kg}^{-1}\right)$ and test weight $\left(42.3 \mathrm{~g} \mathrm{~cm}^{-3}\right)$ were greatest following early-planted radish; however, no significant difference in grain yields occurred in moderate- (2013) and high-yield (2014) environments at preplant $\mathrm{N}$ rates typical for this region. This was similar to other research evaluating corn's rotational response to cover crops with radish (Lawley et al., 2011). However, there is some research that has shown a yield increase in subsequent crops such as sweet corn following radish (Malik et al., 2008) which was related to increased weed suppression. Radish taproots may also reduce soil compaction and provide root channels for the rotational crop. Channels produced by cover crop roots in the autumn and winter, when soils are relatively moist, may facilitate the penetration of compacted soils by subsequent crop roots in summer when soils are relatively hard and dry (Chen \& Weil, 2011; Creswell \& Kirkegaard, 1995). Kirkegaard et al. (1993) hypothesized that tap-rooted Brassica crops produce channels in the dense subsoil, which were utilized by the subsequent crop to access water and nutrients as well as increase yield, and they reported that in seasons with adequate rainfall, the yield advantage of wheat grown after the Brassica crop was in the range of $15-25 \%$ greater compared with a wheat mono-crop which was unlike our research. William and Weil (2004) suggested that roots of summer crops grew following channels created by preceding cover crops which provided lower resistance channels for soybean roots to search for water in the subsoil late in the season during drought thus increasing soybean yields to $200 \mathrm{~kg} \mathrm{ha}^{-1}$ and the impacts of preceding cover crops were greatest during severe drought and highly compacted soil conditions. Evaluating radish, rapeseed and winter rye (Secale cereale L.) as cover crops followed by corn, radish and rapeseed were the most effective in reducing the effects of soil compaction on corn with corn having more roots at a $45 \mathrm{~cm}$ depth in the forage radish treatments (Chen \& Weil, 2011). It is possible that we did not observe increases in subsequent corn yields due to sufficient rain fall during the corn groth periods in 2013 and 2014 (data not presented) and thus possible impacts from the radish were not observed.

Table 2. Winter annual weed control prior to burndown herbicide application and corn response to radish planting date the previous year. Data were averaged over $\mathrm{N}$ application amount and year in the absence of a significant interaction.

\begin{tabular}{|c|c|c|c|c|c|c|c|c|c|c|c|c|c|}
\hline \multirow{2}{*}{$\begin{array}{l}\text { Radish } \\
\text { seeding date }\end{array}$} & \multicolumn{2}{|c|}{ Chickweed } & \multicolumn{2}{|c|}{ Henbit } & \multirow{2}{*}{$\begin{array}{l}\text { Plant } \\
\text { density }\end{array}$} & \multicolumn{4}{|c|}{ SPAD } & \multirow{2}{*}{ Moisture } & \multirow{2}{*}{$\begin{array}{l}\text { Grain } \\
\text { density }\end{array}$} & \multicolumn{2}{|c|}{ Yield } \\
\hline & 2013 & 2014 & 2013 & 2014 & & $0^{\dagger}$ & 17 & 33 & 66 & & & 2013 & 2014 \\
\hline & \multicolumn{4}{|c|}{ 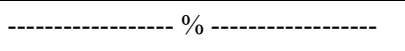 } & No. ha ${ }^{-1}$ & & & & & $\mathrm{~g} \mathrm{~kg}^{-1}$ & $\mathrm{~g} \mathrm{~cm}^{-3}$ & \multicolumn{2}{|c|}{$\mathrm{Mg} \mathrm{ha}^{-1}$} \\
\hline 1 Aug. & 79 & 100 & 81 & 100 & 64,390 & 53.3 & 55.0 & 55.3 & 53.7 & 188 & 42.3 & 9.73 & 12.24 \\
\hline 15 Aug. & 51 & 100 & 72 & 100 & 68,450 & 52.9 & 53.4 & 53.7 & 54.1 & 185 & 41.4 & 9.54 & 12.12 \\
\hline 29 Aug. & 66 & 100 & 51 & 100 & 62,890 & 53.1 & 53.2 & 55.1 & 52.3 & 187 & 41.3 & 9.17 & 12.06 \\
\hline 11 Sep. & 31 & 100 & 29 & 100 & 67,930 & 55.6 & 53.8 & 52.2 & 54.9 & 182 & 41.1 & 9.10 & 12.93 \\
\hline $\operatorname{LSD}(P=0.1)$ & \multicolumn{2}{|c|}{--------9------- } & \multicolumn{2}{|c|}{--------9-------- } & NS & \multicolumn{4}{|c|}{ 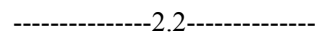 } & 5 & 1.2 & \multicolumn{2}{|c|}{------1.00---- } \\
\hline
\end{tabular}

Note. ${ }^{\dagger} \mathrm{N}$ application amount $\left(0,17,33\right.$, and $\left.66 \mathrm{~kg} \mathrm{~N} \mathrm{ha}^{-1}\right)$. 


\section{Conclusion}

This research took place during drought conditions in 2012 and 2013. In 2012, limited precipitation in summer preceded the planting of radishes, and 2013 saw a flash drought with no precipitation in August and little rainfall September through October. Planting date and $\mathrm{N}$ rate affected radish heights. In general, earlier planting dates produced taller radishes than later ones for all measurement dates across $\mathrm{N}$ rates. Across planting date and year, non-fertilized controls had shorter radishes than any $\mathrm{N}$ rate. The greatest radish heights were produced at $33 \mathrm{~kg} \mathrm{~N}$ $\mathrm{ha}^{-1}$, while radish chlorophyll content did not significantly increase after $33 \mathrm{~kg} \mathrm{~N} \mathrm{ha}^{-1}$. Radish foliage dry biomass production was greatest at the first planting date (1 Aug.) across years. When compared to the other planting dates, foliage dry biomass was 820 to $1670 \mathrm{~kg} \mathrm{ha}^{-1}$ greater with the early planting date. In 2013, winter annual weed suppression was greatest at the first planting date (1 Aug.), but in 2014 no differences in winter annual weed suppression occurred compared to the other planting dates. Radish planting date had no effect on corn yield the following year (2013 and 2014). This research demonstrates that for optimum biomass production, radishes should be planted in late summer prior to $1 \mathrm{Sep}$. and fertilized with $33 \mathrm{~kg} \mathrm{~N} \mathrm{ha}^{-1}$, and that radish planting date likely will not increase corn grain yields in upstate Missouri.

\section{References}

Alam, M. K., Farooque, A. M., Nuruzzaman, M., \& Uddin, A. F. M. J. (2010). Effect of sowing time on growth and yield of three radish (Raphanus sativus L.) varieties. Bangladesh Res. Pub. J., 3, 998-1006.

Altieri, M. A., Lana, M. A., Bettencourt, H. V., Kieling, A. S., Comin, J. J., \& Lovato, P. E. (2011). Enhancing crop productivity via weed suppression in organic no-till cropping systems in Santa Catarina, Brazil. J. of Sustainable Agric., 35, 855-869. http://dx.doi.org/10.1080/10440046.2011.588998

Asghar, H. N., Ishaq, M., Zahir, Z. A., Khalid, M., \& Arshad, M. (2006). Response of radish to integrated use of nitrogen fertilizer and recycled organic waste. Pak. J. Bot., 38, 691-700.

Caviglia, O. P., Sadras, V. O., \& Andrade, F. H. (2004). Intensification of agriculture in the south-eastern Pampas I. Capture and efficiency in the use of water and radiation in double-cropped wheat-soybean. Field Crops Res., 87, 117-129. http://dx.doi.org/10.1016/j.fcr.2003.10.002

Caviglia, O. P., Sadras, V. O., \& Andrade, F. H. (2011). Yield and quality of wheat and soybean in sole- and double-cropping. Agron. J., 103, 1081-1089. http://dx.doi.org/10.2134/agronj2011.0019

Chen, G., \& Weil, R. R. (2011). Root growth and yield of maize as affected by soil compaction and cover crops. Soil \& Tillage Res., 117, 17-27. http://dx.doi.org/10.1016/jstill.2011.08.001

Constantin, J., Mary, B., Laurent, F., Aubrion, G., Fontaine, A., Kerveillant, P., \& Beaudoin, N. (2010). Effects of catch crops, no till and reduced nitrogen fertilization on nitrogen leaching and balance in three long-term experiments. Agric. Ecosys. Enviro., 135, 268-278. http://dx.doi.org/10.1016/j.agee.2009.10.005

Dean, J. E., \& Weil, R. R. (2009). Brassica cover crops for nitrogen retention in the Mid-Atlantic Coastal Plain. J. Environ. Qual., 38, 520-528. http://dx.doi.org/10.2134/jeq2008.0066

Ebrahimi, M., Hassandokht, M. R., \& Payvast, G. H. (2013). Effect of sowing dates on some quantitative and qualitative traits of three landraces of black radish (Raphanus sativus var. niger). Advances in Environ. Bio., 7, 136-140.

Halverson, A. D., Black, A. L., Krupinsky, J. M., \& Merrill, S. D. (1999). Dryland winter wheat response to tillage and nitrogen within an annual cropping system. Agron. J., 91, 702-707. http://dx.doi.org/10.2134/agronj1999.914702

Hochmuth, G., Hanlon, E., Snyder, G., Nagata, R., \& Schueneman, T. (2009). Fertilization of sweet corn, celery, romaine, escarole, endive, and radish on organic soils in Florida. Florida Coop. Ext. Serv. BUL313.

Hoffbeck, C., Ruhland, J., Miller, J., \& Millar, J. (2008). Benefits of cover crops in no-till wheat stubble. Field Facts: Pioneer Agron. Sci., 8, 1-4.

Kirkegaard, J. A., Angus, J. F., Gardner, P. A., \& Creswell, H. P. (1993). Benefits of Brassica break crops in the southeast wheatbelt. Proc. $7^{\text {th }}$ Australian Agronomy Conference Adelaide. Aust. Soc. of Agron., 282-285.

Kristensen, H. L., \& Thorup-Kristensen, K. (2004). Root growth and nitrate uptake of three different catch crops in deep soil layers. Soil Sci. Soc. Am. J., 68, 529-537. http://dx.doi.org/10.2136/sssaj2004.0529

Lawley, Y. E., Teasdale, J. R., \& Weil, R. R. (2012). The mechanism for weed suppression by a forage radish cover crop. Agron. J., 104, 205-214. http://dx.doi.org/10.2134/agronj2011.0128 
Lawley, Y. E., Weil, R. R., \& Teasdale, J. R. (2011). Forage radish cover crop suppresses winter annual weeds in fall before corn planting. Agron. J., 103, 137-144. http://dx.doi.org/10.2134/agronj2010.0187

Liu, B., Liu, X., Li, Y., \& Herbert, S. J. (2013). Effects of enhanced UV-B radiation on seed growth characteristics and yield components in soybean. Field Crop Res., 154, 158-163. http://dx.doi.org/10.1016/j.fcr.2013.08.006

Malik, M. S., Norsworthy, J. K., Culpepper, S., Riley, M. B., \& Bridges Jr., W. (2008). Use of wild radish (Raphanus raphanistrum) and rye cover crops for weed suppression in sweet corn. Weed Sci., 56, 588-595. http://dx.doi.org/10.1614/WS-08-002.1

Mohammadi, G. R. (2013). Alternative weed control methods: A review, weed and pest control - Conventional and new challenges. In S. Soloneski (Ed.), InTech. http://dx.doi.org/10.5772/54164

Norsworthy, J. K. (2003). Allelopathic potential of wild radish (Raphanus raphanistrum). Weed Tech., 17, 307-313. http://dx.doi.org/10.1614/0890-037X(2003)017[0307:APOWRR]2.0.CO;2

Pandey, B. P., Basnet, K. B., Bhatta, M. R., Sah, S. K., Thapa, R. B., \& Kandel, T. P. (2013). Effects of row spacing a direction of sowing on yield and yield attributing characters of wheat cultivated in Western Chitwan, Nepal. Agric. Sci., 4, 309-316.

Pell, E. J., Sinn, J. P., Eckardt, N., Vinten Johansen, C., Winner, W. E., \& Mooney, H. A. (1993). Response of radish to multiple stress II. Influence of season and genotype on plant response to ozone and spoil moisture deficit. New Phytol., 123, 153-163. http://dx.doi.org/10.1111/j.1469-8137.1993.tb04541.x

Ritchie, S. W., Hanway, J. J., \& Benson, G. O. (1993). How a corn plant develops (p. 21). Spec. Rep. 48. Iowa State Coop. Ext. Serv., Ames.

Sapkota, T., Askegaard, M., Laegdsmand, M., \& Olesen, J. E. (2012). Effects of catch crop type and root depth on nitrogen leaching and yield offspring barley. Field Crops Res., 125, 129-138. http://dx.doi.org/10.1016/j.fcr.2011.09.009

Sanchez, C. A., Ozaki, H. Y., Schiler, K., \& Lockart, M. (1991). Nitrogen fertilization of radishes on Histosols: Response and ${ }^{15} \mathrm{~N}$ recovery. HortSci., 26, 865-867.

Sanford, J. O., Myhre, D. L., \& Merwine, N. C. (1973). Double cropping systmes involving no-tillage and $\begin{array}{lllll}\text { conventional } & \text { tillage. } & \text { Agron. } & \text { J., } & 65,\end{array}$ http://dx.doi.org/10.2134/agronj1973.00021962006500060040x

SAS Institute. (2010). SAS user's guide. SAS Inst., Cary, NC.

Schmitt, J., Ehrhardt, D. W., \& Cheo, M. (1986). Light-dependent dominance and suppression in experimental radish populations. Ecology, 67, 1502-1507. http://dx.doi.org/10.2307/1939081

Sharma, A. K. (2000). Effect of nitrogen and phosphorus on seed yield in radish (Raphanus sativus L.). Agric. Sci, Digest, 20, 46-49.

Snapp, S. S., Swinton, S. M., Labarta, R., Mutch, D., Black, J. R., Leep, R., ... O’Neil, K. (2005). Evaluating cover crops for benefits, costs, and performance within cropping system niches. Agron. J., 97, 322-332.

Sojka, R. E., Karlen, D. L., \& Busscher, W. J. (1991). A conservation tillage update from the Costal Plain Soil and Water Conservation Center of South Carolina: A review of previous research. Soil and Tillage Res., 21, 361-376. http://dx.doi.org/10.1016/0167-1987(91)90031-R

Stivers-Young, L. (1998). Growth, nitrogen accumulation, and weed suppression by fall cover crops following early harvest of vegetables. HortSci., 33, 60-63.

Suge, H., \& Rappaport, L. (1968). Role of gibberellins in stem elongation and flowering in radish. Plant Physiol., 43, 1208-1214. http://dx.doi.org/10.1104/pp.43.8.1208

Teasdale, J. R. (1996). Contribution of cover crops to weed management in sustainable agricultural systems. $J$. Prod. Agric., 9, 475-479. http://dx.doi.org/10.2134/jpa1996.0475

Thiessen Martens, J. R., Hoeppner, J. W., \& Entz, M. H. (2001). Legume cover crops with winter cereals in Southern Manitoba: Establishment, productivity, and microclimate effects. Agron. J., 93, 1086-1096. http://dx.doi.org/10.2134/agronj2001.9351086x

Uremis, I., Arslan, M., Uludag, A., \& Sangun, M. K. (2009). Allelopathic potentials of residues of 6 brassica species on johnsongrass [Sorghum halepense (L.) Pers.]. African J. of Biotech., 8, 3497-3501. 
Vos, J., van der Putten, P. E. L., Hussien, M. H., van Dam, A. N., \& Leffelaar, P. A. (1998). Field observations on nitrogen catch crops II. Root length and root length distribution in relation to species and nitrogen supply. Plant and Soil, 201, 149-155. http://dx.doi.org/10.1023/A:1004367530320

William, S. M., \& Weil, R. R. (2004). Crop cover root channels may alleviate soil compaction effects on soybean crop. Soil Sci. Soc. Am. J., 68, 1403-1309. http://dx.doi.org/10.2136/sssaj2004.1403

Zhang, L., Allen Jr., L. H., Vaughan, M. M., Hauser, B. A., \& Boote, K. J. (2014). Solar ultraviolet radiation exclusion increases soybean internode lengths and plant height. Agri. and Forest Meteorol., 184, 170-178.

\section{Copyrights}

Copyright for this article is retained by the author(s), with first publication rights granted to the journal.

This is an open-access article distributed under the terms and conditions of the Creative Commons Attribution license (http://creativecommons.org/licenses/by/3.0/). 